BARBARA GAWDA

Uniwersytet Marii Curie-Skłodowskiej w Lublinie*
KaLINa Kosacka

Uniwersytet Marii Curie-Skłodowskiej

w Lublinie**

\title{
Obraz zaburzeń emocjonalnych w autonarracji K.R. Jamison
}

\author{
Picture od Emotional Disorders in the K.R. Jamison's Self-narration
}

\begin{abstract}
The aim of this work is to reconstruct the picture of emotional disorders as revealed in Jamison's self-narration. The starting point was the question whether self-narration can be a source of information about the patterns of experience of disorder. The self-narrations expressed in the book An Unquiet Mind have been analyzed. The picture of emotional disorders has been reconstructed including the course of depressive and manic episodes and their alternations. The Jamison's personal description of the experience of disorder was a valuable record of the perception of her own and the world.
\end{abstract}


* Zakład Psychologii Emocji i Poznania Instytutu Psychologii UMCS Plac Litewski 5, 20-080 Lublin e-mail: basia.gawda@poczta.umcs.lublin.pl

** Zakład Psychologii Emocji i Poznania Instytutu Psychologii UMCS Plac Litewski 5, 20-080 Lublin e-mail: kalina.lukasiewicz@gmail.com 


\section{Wstęp}

Przedmiotem analizy w niniejszym artykule sa autonarracje Key Redfield Jamison dotyczące przeżywania przez nią choroby afektywnej dwubiegunowej. Cel pracy stanowi odtworzenie obrazu zaburzeń emocjonalnych, zawartego w wypowiedziach osoby chorej. Analizą dyskursu w obrębie psychologii zajmuje się psychologia narracji. Opiera się ona na założeniu, że w wypowiedziach można zidentyfikować manifestacje procesów i mechanizmów psychicznych człowieka, które leżą u ich podstaw. Analiza narracji ma szerokie zastosowanie zwłaszcza w psychologii klinicznej — w diagnozie psychologicznej, psychopatologii i diagnozie klinicznej oraz psychoterapii. Narracje tworzone przez jednostki pozwalają na odtworzenie subiektywnych, unikatowych znaczeń, które tworzą wewnętrzny świat człowieka. Umożliwia to dotarcie do takich informacji, których nie można uzyskać za pomoca innego rodzaju metod, np. kwestionariuszy psychologicznych. W badaniach narracyjnych w sposób szczególny uwidacznia się ogromne znaczenie humanistyki dla poznania i zrozumienia człowieka.

\section{Narracja jako sposób poznania umysłu}

Narracja, opowieść, historia będą przedmiotem niniejszego opracowania. Ich wartość polega w szczególności na tym, iż pozwalają na odtworzenie czy odczytanie bezcennych zindywidualizowanych komunikatów na temat życia człowieka, jego emocji, doświadczeń, sposobu spostrzegania siebie i świata. Ta niezwykła wartość narracji wynika z faktu, iż narracja jest formą dyskursu posiadającą określoną strukturę oraz ujawniającą znaczenia (Gawda 2007b: 95). Podkreśla się, iż tekst i dyskurs są pojęciami równoznacznymi. Ricoeur akcentując znaczeniową strukturę narracji, pisze, iż „tekst nie tylko mówi coś, ale też mówi o czymś” (1989: 46). Dyskurs narracyjny zatem może być pojmowany jako znaczenie. A precyzyjniej, dyskurs narracyjny uznawany jest za strukturę znaczenia rozwijającą się w czasie (Rosner 2003: 5-6). Analizy dyskursu narracyjnego, narracji wywodzą się z teorii hermeneutycznych. Metodologia narracyjna ma charakter heurystyczny, zmierza zatem do interpretacji i rozumienia (Gawda 2007a: 79). W koncepcjach narracyjnych pojawiły się poglądy, iż narracja z jednej strony umożliwia zapis znaczeń, a analiza tego zapisu jest sposobem poznania człowieka, z drugiej zaś, iż narracja jest sposobem czy formą tworzenia 
reprezentacji poznawczej różnych zjawisk u człowieka (Straś-Romanowska, Bartosz i Żurko 2010a, 2010b). Nośnikiem informacji w narracji jest język. Narracyjne tworzenie, konstruowanie przebiega na różnych płaszczyznach i poziomach od najbardziej szczegółowego do ogólnego odnoszącego się do tożsamości człowieka. „Myślenie (samorozumienie) staje się podstawowym czynnikiem konstruującym tożsamość jednostki”, jak podaje Rosner (2003: 6). Konstruowanie umysłowych reprezentacji, własnej tożsamości afektywnej (jej istotnym elementem są emocje, uczucia) opiera się na refleksji autonarracyjnej (Stemplewska-Żakowicz 2002: 81-115).

$\mathrm{Na}$ uniwersalność narracji wskazuje ważna koncepcja w obszarze psychologii narracji, tj. ujęcie Trzebińskiego (Narracja jako sposób rozumienia świata 2002; Trzebiński 2002). Ujmuje on narrację jako strukturę poznawczą. Zakłada, iż ogólna wiedza o świecie kodowana w umyśle człowieka przyjmuje postać narracyjną. Narracja człowieka może zatem wyrażać sposób rozumienia świata. Co więcej, proces rozumienia opiera się na pewnych schematach narracyjnych. Schematy narracyjne mają określoną strukturę i dzięki niej stanowia pewną uniwersalną formę organizowania doświadczenia, zarówno o charakterze społecznym, jak i indywidualnym (Gawda 2007b: 97). W ten sposób Trzebiński wyjaśnia, jak formuje się obraz świata i siebie. Odwołuje się tutaj do teorii Brunera, który zakłada, że istnieją ogólnie dwa sposoby myślenia: pierwszy paradygmatyczny — ujmujący świat i zdarzenia według zasad logiki, drugi zaś narracyjny — nieoperujący kategoriami przyczynowo-skutkowymi, lecz odwołujący się do intencji, celów, pragnień, uczuć (Bruner 1991: 1-20). Ze względu na to, iż narracyjny sposób myślenia powiązany jest z indywidualnym doświadczeniem (ze sferą afektywna), konstruowane przez osobę narracje i autonarracje w większym stopniu odzwierciedlają emocje i uczucia. Koncepcje narracyjne wskazuja, iż istnieje związek pomiędzy kategorią narracji a osobistym systemem znaczeń człowieka, jego emocji, uczuć, sposobu postrzegania świata i siebie. Kolejną koncepcja, która wyjaśnia ten związek, jest teoria Teuna van Dijka (1997: 189-226). Traktuje ona model kontekstu narracji jako poznawczą strukturę skryptopodobna. W takiej strukturze obecne są następujące elementy: miejsce, czas, okoliczności, otoczenie, cele, uczestnicy, ich role, aktualna relacja pomiędzy uczestnikami, globalne (ponadsytuacyjne) relacje pomiędzy uczestnikami, przynależność uczestników do grup i kategorii społecznych. Tak pojmowany model kontekstu według van Dijka pozwala zrozumieć sens i znaczenie danej sytuacji. Model kontekstu ujawniany w narracji zawiera wszystkie elementy schematu mentalnego (kognitywnego); van Dijk zakłada równoległa aktywność obu modeli. To oznacza, iż w narracji dochodzi do odzwierciedlenia obrazu umysłu (Dijk 1997: 189-226).

Podobnie ujmuje relacje pomiędzy strukturą tekstu a umysłem teoria Kaup (za: Gawda 2010: 254). Pomiędzy reprezentacją lingwistyczną a schematami sytuacyjnymi, które konstytuują system wiedzy i stanowia komponent osobowości, istnieja związki (Kaup 2001). Oznacza to, iż istnienie dwu rodzajów reprezentacji, tj. sytuacyjnej i lingwistycznej, daje możliwość poznania jednej reprezentacji poprzez drugą. Zatem poprzez reprezentację lingwistyczną można dotrzeć do reprezentacji emocjonalnej, czyli ukazać obraz sfery emocjonalnej czy umysłu osoby. Oba rodzaje reprezentacji: lingwistyczna i sytuacyjna (model sytuacji) biorą udział w rozumieniu języka. Osoba najpierw tworzy symulację percepcyjną określonej sytuacji, sięgając do jej modelowej reprezentacji, a następnie sięga do reprezentacji lingwistycznej, poszukując odpowiednich zasobów wyrażenia tego, co chce. Istnieje pewnego rodzaju spójność pomiędzy tymi reprezentacjami. Oznacza to, 
iż poznanie reprezentacji lingwistycznej, na przykład poprzez narrację, może dostarczyć istotnych informacji na temat reprezentacji sytuacji, emocji i uczuć przeżywanych przez osobę (Gawda 2010: 254).

Bazując na omówionych założeniach teorii narracji, koncentrujemy się na dwu podstawowych właściwościach. Z jednej strony, iż narracja jest formą konstruowania i zapisu indywidualnych doświadczeń i znaczeń człowieka, z drugiej zaś, iż narracja umożliwia poznanie tych doświadczeń i znaczeń w procesie analizy osobistych historii. W takim kontekście analizie zostanie poddana narracja Kay Redfield Jamison cierpiącej na zaburzenia afektywne. Jamison jest psychologiem, terapeuta i naukowcem. Pracuje jako profesor psychiatrii i prowadzi badania w zakresie chorób afektywnych (związanych głównie z zaburzeniami nastroju). Jest autorką znaczących prac w tym obszarze, takich jak Manic-Depressive Illness (we współautorstwie z Frederickiem Goodwinem) czy Touched with Fire, w której przedstawiła wpływ choroby afektywnej na funkcjonowanie wybitnych twórców. Jednocześnie Jamison sama od młodzieńczych lat cierpi na dwubiegunowe zaburzenie afektywne. W stanie bardzo nasilonej depresji usiłowała popełnić samobójstwo. Swoje doświadczenia wieloletnich zmagań z chorobą opisała na kartach książki Niespokojny umyst. Pamiętnik nastrojów i szalenstwa (2000).

\section{Zaburzenia nastroju (afektywne)}

Opowieść Jamison w książce Niespokojny umyst to autonarracja o życiu pełnym emocji skrajnych i nieprzewidywalnych. To historia cierpienia i prób podnoszenia się z bólu. To obraz niezwykle bogaty, przenikliwy, pozwalający zrozumieć, czym jest doświadczanie zaburzenia określanego w psychopatologii mianem zaburzenie afektywne dwubiegunowe.

Według psychiatrów zaburzenia afektywne nie są homogeniczną grupą zaburzeń (Carson, Butcher i Mineka 2003: 320-323; Cierpiałkowska 2007: 240). Choć określenie qaburzenia nastroju (afek.tywne) wskazuje, iż dotyczą głównie sfery emocjonalno-motywacyjnej człowieka, to jednak ich przejawy obecne są także w innych sferach, na przykład w sferze poznawczej. Ze względu na to, iż zaburzenia afektywne charakteryzują się dużym stopniem zróżnicowania oraz różnym stopniem nasilenia, dzielone są na grupy: dwubiegunowe i jednobiegunowe (zaburzenia depresyjne), zaburzenia afektywne dwubiegunowe typu I i typu II (uwzględnia się epizod łagodny, umiarkowany, ciężki; ICD-10 1996; Butcher, Hooley i Mineka 2017: 274). Nie ma też zgodności pomiędzy badaczami co do ich postaci i objawów psychopatologicznych. Stąd odmienności w tym zakresie pomiędzy międzynarodową klasyfikacją ICD-10 a amerykańską klasyfikacją DSM-IV (1994), DSM-IV-TR (2000) czy DSM-V (2013). Ogólnie przyjmuje się, że zaburzenia afektywne pojawiają się najczęściej pomiędzy piętnastym a trzydziestym rokiem życia, choć moga występować w każdej fazie cyklu życia. Według Międzynarodowej Klasyfikacji ICD-10 (1996) występuja w takich postaciach jak epizod maniakalny, zaburzenia afektywne dwubiegunowe, epizod depresyjny, uporczywe zaburzenia nastroju, inne zaburzenia nastroju, zaburzenia nastroju nieokreślone. Najbardziej rozpowszechnione typy zaburzeń nastroju to depresje, czyli epizody depresyjne, a także epizody maniakalne i dwubiegunowe zaburzenie afektywne (ICD-10 1996). W najnowszej klasyfikacji zaburzeń DSM-V (2013) ujmowane sa one odrębnie jako zaburzenia depresyjne i zaburzenia afektywne dwubiegunowe. W zakresie dwubiegunowych zaburzeń wyodrębnia się zaburzenia dwubiegunowe typu I i typu II, zaburzenia cyklotymiczne oraz wiele innych (DSM-V 2013). Istotne jest, iż dla wszystkich 
tych zaburzeń charakterystyczne są zmiany w zakresie doświadczanych emocji. Zmiany te mają charakter poważnych i długotrwałych, co w efekcie prowadzi do różnorodnych problemów zawodowych, interpersonalnych czy społecznych. Ma to kluczowy wpływ na jakość życia osób na nie cierpiących.

\section{Depresja i narracja w depresji Jamison}

Istotą epizodu depresyjnego zgodnie z opisami psychopatologów jest to, iż charakteryzuje się on obniżeniem nastroju, utratą zainteresowań i zdolności do czerpania przyjemności i radości z życia (tzw. anhedonia), zmniejszoną energia, co przejawia się w męczliwości i obniżonej aktywności (Carson, Butcher i Mineka 2003: 327-329; Hammen 2004). W narracji Jamison taki stan emocjonalny pojawia się bardzo często, towarzyszy jej codziennie w czasie doświadczania depresji, od najwcześniejszych godzin porannych do zmierzchu dnia, czyniąc jej życie pozbawionym szczęścia, zadowolenia, radości. Jamison podkreśla, iż odczucia negatywne charakteryzują się w takim stanie psychicznym niezwykłą intensywnością, co prowadzi do charakterystycznego postrzegania siebie i otoczenia. Stała się dla siebie kimś „,niezdolnym do odrobiny radości”, kimś, kto utracił coś wartościowego, kimś „nudnym, męczącym (...) pozbawionym życia i bezbarwnym”:

Od momentu wstania z łóżka do czasu położenia się spać byłam nieznośnie nieszczęśliwa, niezdolna do odrobiny radości czy entuzjazmu. Wszystko — każda myśl, słowo, ruch — było wysiłkiem. Wszystko, co niegdyś błyszczało, teraz wyblakło. Wydawałam się sobie nudna, męcząca, niedostosowana, spowolniała, tępa, nie reagująca, zimna, pozbawiona życia i bezbarwna.

(Jamison 2000: 99)

Wśród przeżyć emocjonalnych, jakich doświadcza, emocji i uczuć dominują smutek, przygnębienie, odrętwienie, cierpienie, niepokój i lęk. Takie stany Jamison oddziałują na jej sferę motywacyjna. Zaburzenie motywacji przyjmuje zgodnie z danymi z literatury przedmiotu postać od bierności do wycofania się z pełnionych dotychczas ról (Carson, Butcher i Mineka 2003: 327-329). Dochodzi do obniżenia zainteresowania różnymi sferami życia, a nawet do braku zainteresowania zaspokajaniem podstawowych potrzeb biologicznych, jak głód, pragnienie (Czabała 2000: 593). Taki stan wycofania i izolacji od innych, poczucia beznadziejności coraz bardziej, jak relacjonuje w autonarracji, ogarnia Jamison. Jej relacje z innymi stają coraz bardziej ograniczone. Bliscy i przyjaciele przestają być ważni dla niej. Przyznaje, iż „unikała przyjaciół”, „rozmawiała bardzo niewiele”, „czuła się całkowicie samotna”. Pomimo iż celem jej działań i dążeń były próby „uniknięcia smutku i pustki”, to silne negatywne emocje i bardzo obniżony poziom motywacji znacząco jej to utrudniały. Kluczową rolę utrudniającą odgrywały tutaj nie tylko ogromny smutek, poczucie rozpaczy i przygnębienia, które odczuwa Jamison, ale też niezwykle nasilony lęk przed innymi ludźmi i wszelkimi przejawami społecznego funkcjonowania. Intensywne odczucia lękowe wpływały blokująco na jej aktywność i relacje interpersonalne:

Byłam przerażona, gdy musiałam z kimś rozmawiać, unikałam przyjaciół, gdy tylko było to możliwe, i przesiadywałam w szkolnej bibliotece wcześnie rano i późno po południu, całkowicie bierna, z martwym sercem i mózgiem chłodnym jak kawałek lodu. (Jamison 2000: 37-38) 
Rozumiałam bardzo niewiele z tego, co działo się dookoła, i czułam się tak, jakby tylko śmierć mogła wybawić mnie od wszechogarniającego poczucia nieadekwatności i rozpaczy, które mnie dotykało. Czułam się całkowicie samotna (...). Przestałam odbierać telefony i korzystałam z długich gorących kąpieli, mając próżną nadzieję, że w jakiś sposób uda mi się uniknaćc smutku i pustki. (Jamison 2000: 42-43)

Jamison doświadcza przeróżnych form i niuansów depresji, które ukazuje w swojej opowieści. Epizod depresyjny może przyjmować postać łagodną bez objawów somatycznych bądź z takimi objawami, umiarkowaną bądź ciężką. W przypadku ciężkiego epizodu depresyjnego mogą pojawić się objawy psychotyczne w postaci halucynacji czy urojeń. Epizod depresyjny może przyjmować także postać zaburzeń depresyjnych nawracających, w którym oprócz wspomnianych zaburzeń nastroju mogą ale nie muszą pojawić się objawy somatyczne (ICD-10 1996; Czabała 2000: 593). Oprócz wymienionych objawów epizodu depresyjnego charakterystyczne jest obniżenie napędu psychomotorycznego, co odzwierciedla się w spowolnionym tempie wykonywania czynności, reakcji na bodźce, mówieniu (Cierpiałkowska i Sęk 2008: 561). Jamison ujawnia w autonarracji, iż doświadcza trudności w zakresie koncentracji na całej gamie spraw, poczynając od codziennych czynności do aktywności bardziej złożonych, zawodowych. Nie jest w stanie „wstać z łóżka”, zmienić ubrania, czytać, spacerować itd.:

Byłam całkowicie wyczerpana i z trudem mogłam rankiem wstać z łóżka. Dwa razy więcej czasu niż zwykle zajmowało mi dotarcie wszędzie tam, gdzie zwykle chodziłam. Nosiłam cały czas te same rzeczy, ponieważ decyzja o tym, co na siebie włożyć, kosztowała mnie zbyt wiele wysiłku. (Jamison 2000: 37)

(...) tak jak noc nieuchronnie przychodzi po dniu, mój nastrój załamywał się, a umysł gwałtownie się zatrzymywał. Traciłam zainteresowanie nauką, przyjaciółmi, czytaniem, wędrowaniem i marzeniami. (Jamison 2000: 42)

Permanentne odczuwanie zmęczenia odzwierciedla się nie tylko w obniżeniu aktywności codziennej, ale też w stosunku do siebie samej. Zaczyna postrzegać siebie jako osobę „nieciekawą”, szarą, ale też obcą i pozbawioną chęci do życia: „Każdego dnia budziłam się bardzo zmęczona, a uczucie to było tak obce mojemu prawdziwemu ja, jak bycie znudzoną lub obojętną na bieg życia" (Jamison 2000: 38). Odczucie wyczerpania, przeżywanie smutku i rozpaczy, osłabienie motywacji, unikanie kontaktów, wycofanie się z aktywności społecznej współwystępuja z zaburzeniami funkcjonowania poznawczego w postaci spowolnienia toku myślenia, osłabienia zdolności zapamiętywania i osłabienia koncentracji uwagi (Czabała 2000: 593; Cierpiałkowska 2007: 246). W efekcie nie jest możliwa jakakolwiek aktywność poznawcza, jak wskazuje Jamison. Jej „,umysł pogrążył ją”, „wielokrotnie czyta to samo zdanie”, „,nie pamięta nic z tego, co przeczytała”. To, co czyta, jest „niezrozumiałe”, aż wreszcie prowadzi to do poczucia, „iż nic nie ma sensu”:

Później moje życie i umysł pogrążyły się całkowicie. Czytałam wielokrotnie to samo zdanie, tylko po to, by uświadomić sobie, że nie pamiętam nic z tego, co przeczytałam. Z każdą książką lub wierszem, po który sięgałam, działo się to samo. Były niezrozumiałe. Nic nie miało sensu. 
(...) mój umysł zwrócił się przeciwko mnie: kpił z mojego nieuzasadnionego entuzjazmu; śmiał się ze wszystkich nierozsądnych planów; nie znajdował wokół nic interesującego, zabawnego ani wartego zastanowienia. Był niezdolny do skoncentrowania myśli (...). (Jamison 2000: 37)

Funkcjonowanie umysłu w stanie ciężkiej depresji może ponadto być, jak już wspomniano, zaburzone poprzez objawy psychotyczne. Epizod depresyjny z objawami psychotycznymi charakteryzuje się utratą kontaktu z rzeczywistością w efekcie urojeń (np. urojeń grzeszności) oraz zaburzona percepcją rzeczywistości w postaci halucynacji (Cierpiałkowska 2007: 246; Butcher, Hooley i Mineka 2017: 283). Jamison doświadcza takich stanów, przeżywa halucynacje, dostrzega przedmioty, zjawiska, które obiektywnie nie istnieja, widzi postaci, które towarzysza jej, będąc jedynie wytworami zaburzonego umysłu. Jej percepcja rzeczywistości traci znamiona normy. Wytwory zaburzonego umysłu są obecne w jej doświadczeniu:

Powoli ciemność zaczynała wkraczać do mojego umysłu (...). Pewnego wieczoru stałam pośrodku pokoju i patrzyłam na krwawoczerwony zachód słońca rozpościerający się nad horyzontem Pacyfiku. Nagle doznałam dziwnego poczucia światła z tyłu moich oczu i niemal natychmiast ujrzałam ogromną, czarną wirówkę w mojej głowie. Spostrzegłam wysoką postać w czarnej todze sięgającej do podłogi, która zbliżyła się do wirówki z probówką wielkości wazonu, pełną krwi. (Jamison 2000: 72-73)

Znawcy problematyki podkreślają, iż osoba cierpiąca na depresję może doświadczać zaburzeń rytmu biologicznego w postaci zaburzeń snu czy cyklu miesięcznego, a także licznych objawów somatycznych, jak bóle różnych części ciała, zaburzenia żołądkowo-jelitowe czy suchość błon śluzowych jamy ustnej (Carson, Butcher i Mineka 2003: 329). W tak ekstremalnym stanie pojawiają się także myśli i fantazje samobójcze (Gawda 2000: 141; 2003: 76). Jamison doświadcza zarówno cierpienia fizycznego, jak i psychicznego — ma poczucie nieadekwatności i bezsensowności swojego istnienia. Ma świadomość, iż jej stan psychofizyczny jest źródłem kłopotów, trudności, to poczucie nasila się aż do stadium, w którym formułuje kluczowe egzystencjalne pytania. Zadaje sobie pytanie o sens jej życia. Ma poczucie, iż jest kompletnie bezużyteczna, „nie może niczego przeżywać”, „nie może myśleć” ani też „troszczyć się o innych”. Poziom cierpienia jest tak ogromny, iż ma poczucie, że „dłużej nie może go tolerować”. Co więcej, jest też przekonana o tym, że ”jest bezbarwna i męcząca”. Stanowi zatem dla innych obciążenie. To wtórnie jeszcze bardziej nasila poczucie bezsensowności jej życia:

„Jaki sens ma takie życie?” — zadawałam sobie pytanie (...) Wielokrotnie powtarzałam sobie: jeśli nie mogę nic przeżywać, jeśli nie mogę się ruszać, jeśli nie mogę myśleć i nie mogę troszczyć się o innych, jaki sens ma moje życie? (Jamison 2000: 99)

Nie mogłam dłużej tolerować cierpienia, nie mogłam znieść całkowicie bezbarwnej i męczącej osoby, którą się stałam, i czułam, że nie potrafię dłużej odpowiadać za kłopoty sprawiane rodzinie i przyjaciołom. (Jamison 2000: 103)

Depresja Jamison obfitująca w emocjonalne doświadczanie rozpaczy, przygnębienia, poczucie bezradności i bezsilności, a także poczucie stagnacji umysłowej, w sposób naturalny prowadzą do koncentracji na śmierci samobójczej jako jedynej drodze do rozwiązania swoich problemów: 
Przewrotny komunikat, który wydawał mój umysł, sprawiał, że myślałam: (...) zabiję się, gdyż jest to jedyna rozsądna rzecz, jaką mogę zrobić dla osób, o które się troszczę; było to również jedyne sensowne rozwiązanie dla mnie. (Jamison 2000: 103)

Zainteresowanie mojego umysłu umieraniem było zdumiewające: śmierć i tematy z nią związane stale mi towarzyszyły. Widziałam śmierć wszędzie, w mojej wyobraźni powstawały obrazy prześcieradeł pokrywających zwłoki, karteczek identyfikujących zmarłych i foliowych toreb na ciała. Każda rzecz przypominała o tym, że wszystko kończy się w kostnicy. (Jamison 2000: 100)

Śmierć jest pewnego rodzaju wybawieniem od obecnego stanu rzeczy, wybawieniem, które może pozwolić zakończyć cierpienie. Nawiązując do ujmowania narracji jako wyrazu osobistego systemu znaczeń (np. Bruner 1991), można wskazać na podstawowe elementy, które ujawnia w swojej autonarracji Jamison w postaci emocji, uczuć, postrzegania świata i siebie. Pragnie śmierci, ponieważ świat, w którym żyje, jest odległy i niedostępny, niepojęty, pełen cierpienia i udręki. Nie wierzy w siebie, w swoje możliwości, jej samoocena jest bardzo niska. Nie może w takiej sytuacji stanowić równouprawnionego uczestnika ludzkiej społeczności. Sposób postrzegania rzeczywistości jest zdeformowany, zdegradowane są uczucia, myślenie. Świat psychiczny obraca się jak błędne koło wśród pustki, beznadziejności i głębokiej samotności. W takiej sytuacji przyjmuje jeden możliwy swój punkt widzenia o rozwiązaniu i zakończeniu swojego istnienia. Z kolei nawiązując do modelu kontekstu według koncepcji van Dijka (1997) ujawnianego w narracji, można podkreślić, iż autonarracja Jamison wskazuje na szereg ważnych elementów. W stanie depresji relacje narratora $z$ innymi są bardzo ograniczone, jest jedynym uczestnikiem sytuacji, który nie ma siły ani potrzeby kontaktować się z innymi. Jest najczęściej skupiony na swoim cierpieniu, do tego stopnia, iż okoliczności postrzega w sposób bardzo specyficzny, tzn. nadaje im znamiona negatywne. Ponadsytuacyjne relacje pomiędzy uczestnikami scen są również oznakowane negatywnie, to znaczy postrzega siebie jako „bezużyteczną” istotę, stanowiaca „ciężar dla innych”. Czas jest postrzegany ,jakby zatrzymał się”, jakby „stał w miejscu”. Cele i role uczestników sceny mają bardzo ograniczoną postać. Główną ich cechą jest ograniczenie aktywności we wszelkich formach i koncentracja na dominującym, niezwykle silnym negatywnym nastroju. Narracja w depresji Jamison oddaje klimat emocjonalny charakterystyczny dla poczucia cierpienia, przygnębienia i beznadziejności.

\section{Odmienność obrazu manii w narracji}

Według psychologów klinicznych epizod maniakalny może przyjmować postać od hipomanii (czyli łagodnej formy) do ciężkiej współwystępującej z objawami psychotycznymi, na przykład w formie urojeń wielkościowych (Cierpiałkowska 2007: 242; Cierpiałkowska i Sęk 2008: 561). Dla epizodu maniakalnego charakterystyczny jest podwyższony nastrój w postaci pobudzenia, podekscytowania, zadowolenia, dobroduszności, aż do rozdrażnienia, niepokoju i lęku. Znawcy tej problematyki podkreślaja, iż ze zmianami nastroju współwystępuja zmiany w obszarze motywacyjnym — osoba jest dynamiczna, podejmuje różne aktywności pozbawione zahamowań i kontroli (Czabała 2000: 592; DSM-V 2013). Zachowanie i postępowanie osoby w takim stanie jest chaotyczne, niestabilne, mało konsekwentne (Carson, Butcher i Mineka 2003: 335). Osoba nie ma kontroli nad swoimi działaniami, decyzjami, skraca dystans w relacjach z innymi bądź staje się napastliwa i agresywna. Na odmienność doznań w stanie manii w stosunku do tych, które towarzyszyły depresji, 
wskazuje narracja Jamison: „Świat pełen był przyjemności i obietnic; czułam się świetnie. Nie zwyczajnie świetnie, czułam się naprawdę doskonale" (Jamison 2000: 36). Wydaje się, że zakończyło się ,pogrążanie w najczarniejszych zakamarkach umysłu” (Jamison 2000: 61). Stan obfituje w nadaktywność, poszukiwanie wrażeń, podejmowanie licznych inicjatyw, Jamison staje się bardzo towarzyska, ekspansywna, dynamiczna i pełna pomysłów:

Kiedy zaczął się atak, dość szybko straciłam głowę. Początkowo wszystko wydawało mi się bardzo łatwe. Rzucałam się jak zwariowana łasica, kipiąc od planów i entuzjazmu, uczestnicząc w zajęciach sportowych, nie śpiąc całe noce, wychodząc każdego kolejnego wieczoru z przyjaciółmi, czytając o wszystkim, co nie było do końca wyjaśnione, zapełniając zeszyty wierszami i fragmentami sztuk oraz czyniąc ekspansywne i całkowicie nierealistyczne plany dotyczące przyszłości. (Jamison 2000: 36)

Aktywność i działalność Jamison w takim stanie zaczynają zataczać coraz szersze kręgi, obejmują coraz więcej obszarów, niekiedy zupełnie niepowiązanych ze sobą, a nawet wykluczających się:
Zaangażowałam się również w działalność polityczną i społeczna, która obejmowała niemal wszystkie dziedziny, od studenckich ruchów antywojennych do fanatycznych organizacji wal- czących z firmami kosmetycznymi, które zabijały żółwie, aby produkować i sprzedawać środki upiększające. (Jamison 2000: 42)

Pojawiła się potrzeba nawiązywania kontaktów interpersonalnych, które stają się coraz bardziej zaawansowane, a towarzyszy im pełne przekonanie o niebanalności własnej aktywności i własnej osoby. U Jamison wzrasta poczucie własnej wartości aż do ekstremalnych granic:

Pamiętam, że byłam prawdopodobnie w nieco podwyższonym nastroju, a przede wszystkim to, że rozmawiałam z mnóstwem osób, wydając się sobie niesłychanie czarująca (...). Rozmawiałam przez dłuższy czas z rektorem (...), byłam pewna, że odbiera mnie jako niezwykle urzekającą osobę (...). Moje wspomnienia z garden party mówią mi, że bawiłam się cudownie, byłam ujmująca i pewna siebie i miałam szampański nastrój. Jednak mój psychiatra, (...) wspominał to wszystko całkowicie inaczej. Stwierdził, że byłam ubrana w sposób prowokujący (...), miałam znacznie jaskrawszy makijaż niż zwykle i wydawałam się zbyt pobudzona i gadatliwa (...). W przeciwieństwie do niego ja uważałam, że jestem wspaniała. (Jamison 2000: 64-65)

Potrzeba kontaktu z innymi nie ogranicza się tylko do rozmowy, nasilają się także potrzeby stymulacji, doznań, w tym seksualnych, a to za sprawa, z jednej strony, wzrostu pozytywnych emocji u Jamison, a drugiej zaś, wzrostu poczucia własnej wartości:

Nieśmiałość znika, nagle pojawiają się odpowiednie słowa i gesty i jesteś pewna, że potrafisz przekonywać ludzi o słuszności swoich poglądów. Znajdujesz interesujące cechy w pozornie nieciekawych ludziach. Namiętność erotyczna jest wszechogarniająca i czujesz niepohamowaną potrzebę bycia uwodzoną i uwodzenia. (Jamison 2000: 61)

W stanie hipomaniakalnym funkcjonowanie poznawcze wydaje się optymalne. Jamison ma poczucie, że jest zdolna do wytrwalej pracy intelektualnej, że jest owocna i twórcza. Ma przekonanie, iż aktywność ta jest sensowna i celowa: 
Mój umysł był jasny, cudownie skupiony i zdolny do przeprowadzania intuicyjnych matematycznych obliczeń, które osiagały zadziwiającą mnie doskonałość (...) w tym czasie wszystko nie tylko miało sens - zaczęło się nawet układać w cudowne kosmiczne związki.

(Jamison 2000: 36)

Jednocześnie w tym stanie pojawia się bardzo pozytywne postrzeganie siebie, swoich możliwości, przekonanie o swoim ogromnym potencjale i dużej wydajności zawodowej:

Gdy jesteś na szczycie, czujesz się cudownie. Idee i wrażenia przebiegają szybko i często jak wybuchające gwiazdy, podążasz za nimi aż do czasu, gdy znajdziesz coś lepszego i mądrzejszego.

(Jamison 2000: 61)

Jednak nasilający się stan maniakalny nieuchronnie prowadzi do zaburzeń poznawczych w postaci przyspieszenia toku myślenia, gonitwy myśli, powierzchowności bądź wielopłaszczyznowości, a także wielomówności i słowotoku (Cierpiałkowska 2007: 244; Cierpiałkowska i Sęk 2008: 561). Co więcej, pojawiają się bardzo poważne zaburzenia koncentracji uwagi, w czego efekcie wypowiedzi osoby cierpiącej na stan maniakalny sa chaotyczne, niespójne, pozbawione konkretnego kierunku i logiki. Zgodnie z literatura przedmiotu dla epizodu maniakalnego charakterystyczne są także dodatkowe zaburzenia snu i łaknienia, obniżona wrażliwość na ból i dolegliwości somatyczne (ICD-10 1996). Narracja Jamison ukazuje, jak zmieniają się jej zainteresowania warunkowane zaburzeniami koncentracji uwagi, wahaniami uwagi i przyspieszeniem tempa procesów psychicznych:

Gwałtownie zmieniłam zainteresowania na muzykę rockowa, wydobyłam moje płyty Rolling Stonesów i odtwarzałam je tak głośno, jak tylko było to możliwe. Przerzucałam się z utworu na utwór, z albumu na album (...), nie mogłam dłużej przyswajać słyszanych melodii: byłam zagubiona, przerażona i zdezorientowana. Nie mogłam słuchać jakiegokolwiek utworu dłużej niż kilka minut; moje zachowanie, a jeszcze bardziej moje myśli, stały się całkowicie szalone.

(Jamison 2000: 72)

W konsekwencji przyspieszenie tempa myślenia, mówienia i w ogóle funkcjonowania poznawczego Jamison owocuje chaosem psychicznym, jednak osoba cierpiąca w stanie epizodu maniakalnego nie jest w stanie tego kontrolować:

Mój umysł zaczynał odczuwać konieczność znacznego wysiłku, by nadążać za myślami, które pojawiały się tak szybko, że przecinały się pod każdym z możliwych kątów. Powstał ogromny karambol na autostradach mojego mózgu, a im bardziej próbowałam zwolnić bieg myśli, tym mocniej uświadamiałam sobie, że jest to niemożliwe. (Jamison 2000: 65-66)

Ogromne tempo psychiczne uniemożliwia adekwatne reagowanie i funkcjonowanie w świecie, w rzeczywistości społecznej, zawodowej, a to prowadzi do licznych problemów, także interpersonalnych: „„Mówisz zbyt szybko, Kay. Zwolnij, Kay«, powtarzali. Ale nawet gdy tego nie mówili, nadal mogłam wyczytać w ich oczach: »Na miłość boska, Kay, zwolnij tempo«" (Jamison 2000: 36). W końcu to wszystko prowadzi do wyczerpania psychicznego i fizycznego: „Nadal prowadziłam życie w szalonym tempie. Pracowałam całymi godzinami i niemal nie sypiałam. Gdy wracałam wieczorami do domu, stawał się on miejscem narastającego chaosu (...)" (Jamison 2000: 71). 
Narracja Jamison w manii jest nasycona pozytywnymi emocjami, potrzebami społecznymi, poznawczymi i chęcią aktywności. Narracja ta obrazuje, jak bardzo zmienia się poczucie własnej wartości, stosunek do ludzi i świata w porównaniu z tym, który obecny był w depresji. Autonarracja Jamison w manii obejmuje szeroki zakres kontekstu, używając terminologii van Dijka (1997: 189-226), występuje w niej różnorodność i wielość miejsc, okoliczności, celów, warunków, osób oraz relacji pomiędzy tymi osobami, a także perspektyw czasowych. W narracji pojawia się wiele osób, jak koledzy, przyjaciele. Aktywność jest zróżnicowana i wielokierunkowa, osoba stawia sobie wiele celów, formułuje wiele dążeń. Jednak charakterystyczne jest, iż aktywność ta nie prowadzi do realizacji celów, nie jest zatem konsekwentna. Narracja Jamison w depresji odnosi się najczęściej do zawężonej liczby miejsc, okoliczności; uczestnikiem scen jest najczęściej tylko autor narracji, jego cele i plany są ograniczone, zaś relacje z innymi ludźmi zredukowane do minimum. Perspektywa czasowa narracji w depresji jest najczęściej bardzo wąska i polega na odczuwaniu czasu jako błędnego koła (Gawda 2000: 140-142). Perspektywa czasowa w manii jest bardzo szeroka, czas jest postrzegany jako „bardzo szybko biegnacy” i „zmienny”. To wynika z dużej intensywności odczuwanych pozytywnych emocji przez Jamison. Jednak pomimo tego, iż emocje mają charakter pozytywny, a perspektywa czasowa i interpersonalna są szerokie, to stan manii oznacza chaos psychiczny i afektywny, w skutek czego osoba nie jest zdolna do właściwego (adekwatnego do wymogów sytuacyjnych) funkcjonowania.

\section{Naprzemienność stanów w dwubiegunowym zaburzeniu afektywnym}

Według psychopatologów zjawiska omówione powyżej moga pojawiać się w życiu ludzi bądź osobno, bądź też cyklicznie. Dla zaburzenia afektywnego dwubiegunowego (ICD-10 1996) charakterystyczne jest to, iż stany depresyjne i maniakalne występują naprzemiennie (przynajmniej dwa). Najczęściej objawy epizodu manii pojawiają się nagle i trwają krócej niż epizody depresji. Co więcej, w przypadku występowania zaburzeń nastroju i objawów psychotycznych rozpoznaje się zaburzenia afektywne dwubiegunowe z objawami psychotycznymi (F31.5 wg ICD-10 1996). Wcześniej omówione symptomy epizodów manii i depresji mogą w różnym stopniu i w różnych konfiguracjach występować w dwubiegunowym zaburzeniu afektywnym (Carson, Butcher i Mineka 2003: 336; Cierpiałkowska i Sęk 2008: 561-562).

W autonarracji Jamison w pełni ukazana jest ta zmienność. Z jednej strony naprzemienność stanów depresji i manii postrzegana jest przez Jamison jako coś interesującego, dodającego siły i mocy, z drugiej zaś, pozostawiającego poczucie ulotności i nierealności, poczucie, że to wszystko nie dzieje się naprawdę:

Ten wzorzec zmieniających się nastrojów i poziomów energii był jednak z pewnego względu bardzo pociagający, w dużej mierze z powodu okazjonalnych napływów oszałamiającego nastroju (...). Te chwile były całkowicie niezwykłe, przepełniały mój mózg lawiną idei i wystarczająca ilością energii, by dawać mi złudzenie możliwości realizacji tych planów. (Jamison 2000: 40-41)

Oprócz wnikliwej relacji z procesu odczuwania i funkcjonowania w obu stanach Jamison wskazuje na doświadczenia radzenia sobie z owymi stanami. Podkreśla, iż odmienności wprowadziły do jej życia nowe kompetencje, to znaczy umiejętności czerpania wiedzy ze skrajnych emocjonalnie doświadczeń: 
Przebyte liczne stany hipomanii i manii wprowadziły do mojego życia odmienny poziom czucia, przeżywania i myślenia. Nawet wtedy, gdy znajdowałam się całkowicie w stanie psychozy miałam urojenia, omamy i pogrążałam się w szaleństwie — byłam świadoma, że odkrywam nowe zakątki mojego umysłu i mojej duszy (...). (Jamison 2000: 188)

Zwiększona samoświadomość w efekcie analizy skrajnych emocjonalnie doświadczeń oraz zwiększony wgląd we własną chorobę dzięki autorefleksji spowodowały wzrost umiejętności radzenia sobie z zaburzeniem. Pierwotnie trudno było jej zaakceptować chorobę, jak pisze: „(...) nigdy nie wydawało mi się, że jestem chora; mój mózg po prostu nie przyjmował tego do wiadomości" (Jamison 2000: 43).

Przez dłuższy okres trwania swojej choroby Jamison nie dostrzegała jej objawów we własnym funkcjonowaniu. Miało to ogromny wpływ na odraczanie decyzji o podjęciu leczenia. Po latach przyznała, że dwubiegunowa choroba afektywna przynosi choremu szereg korzyści. Stany podwyższonego nastroju i wysokiego poziomu energii umożliwiaja osobie funkcjonowanie powyżej przeciętnych możliwości, co sprawia ogromną przyjemność i wydaje się niezwykle atrakcyjne. To właśnie paradoksalnie powoduje, iż niezwykle trudno jest skłonić osobę chorą do leczenia. Jamison ujawnia w autonarracji oprócz objawów i przeżyć, także swój stosunek do choroby. Jest to wskazanie na osobiste znaczenie choroby w jej życiu. Przyznała, iż pomimo zajmowania się zawodowo oraz naukowo tematyka zaburzeń afektywnych dwubiegunowych, bardzo trudno jej było dostrzec chorobę u siebie. Podkreśla, jak wiele czasu zajęło jej wypracowanie umiejętności wglądu w chorobę i w jej przebieg. Narracja Jamison to nie tylko obraz zmienności stanów emocjonalnych i psychicznych, cierpienia i upadku, ale też ukazanie możliwości i siły człowieka w radzeniu sobie z zaburzeniem psychicznym.

\section{Podsumowanie}

Obraz świata i obraz siebie wyłaniający się z historii Jamison są ściśle powiązane z zaburzeniami emocjonalnymi, których doświadcza. Jej opowieść, jej historia to podróż poprzez meandry skrajności emocjonalnych. To ekspresywna relacja opisująca dokładnie wszystkie objawy pojawiających się naprzemiennie epizodów depresyjnych oraz maniakalnych. W okresach, kiedy „ciemność zaczynała wkraczać do jej umysłu”, Jamison przeżywa szereg negatywnych emocji, takich jak lęk, smutek, przygnębienie czy poczucie beznadziejności. W opowieści należącej do depresji podróż przebiega poprzez „najczarniejsze zakamarki jej umysłu”, w których myśli biegną w sposób spowolniony, wszystko staje się bezsensowne, wyobcowane, powiązane z poczuciem nieadekwatności, włącznie z obsesyjnie dręczącymi ją myślami samobójczymi. Kiedy zaś „świat staje się pełen przyjemności”, życie Jamison nabiera odmiennych barw. W podróży w tym stanie prowadzi czytelnika poprzez niezwykle pozytywne emocje, podekscytowanie, potrzebę niezwykłej aktywności oraz poczucie ponadprzeciętnych zdolności poznawczych. Te objawy przybierają na sile aż do stanu, gdy staja się nieprzyjemne. Towarzyszy im gonitwa myśli, ogromne trudności z koncentracja uwagi, poczucie wszechogarniającego chaosu. Podróż wielokrotnie zmienia swój kierunek, „ciemność” przeplata się z „,jasnością umysłu”, smutek z radościa, pobudzenie z odrętwieniem, zmiany zachodzą coraz szybciej, aż do efektu nakładania się, poczucia chaosu, wyczerpania fizycznego i psychicznego. W podróż wpisane jest cierpienie przyjmujące różne postaci, ale każda z nich uwikłana jest w poczucie braku możliwości uwolnienia się 
od tego bagażu doświadczeń, a także jednoczesne próby obronnego „nieprzyjmowania do wiadomości”, iż jest się chorym. Opowieść Jamison jest nieocenionym zapisem sposobu przeżywania zaburzenia, postrzegania siebie oraz świata w stanie chorobowym. Jej narracja to źródło niezwykle cennych informacji na temat funkcjonowania osoby cierpiącej na dwubiegunowe zaburzenie afektywne. Pozwala lepiej zrozumieć mechanizmy choroby oraz odczucia osoby chorej. Nie jest to jednak narracja spontaniczna, taka, jaką tworzy pacjent będący przeciętną osobą cierpiąca na zaburzenia emocjonalne. Narracja Jamison, oprócz osobistych, zindywidualizowanych wypowiedzeń i sformułowań, jest pełna fachowej terminologii, języka naznaczonego erudycją. Jest to zrozumiałe ze względu na profesję Jamison. Jednak pomimo tego, iż sposób formułowania wypowiedzi, poziom spontaniczności, ich leksykalne czy syntaktyczne aspekty odbiegają wyraźnie od przeciętnej, narracja Jamison pozwala na wniknięcie w świat jej osobistych znaczeń.

\section{Bibliografia}

Bruner Jerome (1991), The Narrative Construction of Reality, „Critical Inquiry”, no 18.

Butcher James, Hooley Jill, Mineka Susan (2017), Psychologia zaburzeń DSM-V, GWP, Sopot. Carson Robert, Butcher James, Mineka Susan (2003), Psychologia zaburžeń, GWP, Gdańsk.

Cierpiałkowska Lidia (2007), Psychopatologia, Scholar, Warszawa.

Cierpiałkowska Lidia, Sęk Helena (2008), Psychopatologia [w:] Psychologia. Podrecznik akademicki, red. J. Strelau, D. Doliński, GWP, Gdańsk.

Czabała Jan Czesław (2000), Podstawowe zaburzenia psychiczne [w:] Psychologia. Podręznik akademicki, t. 3, red. J. Strelau, GWP, Gdańsk.

Dijk Teun A. van (1997), Cognitive Context Models and Discourse [w:] Language Structure, Discourse and the Access to Consciousness, red. M. Stamenow, Benjamins, Amsterdam.

DSM-IV-TR (2000), Diagnostic and Statistical Manual of Mental Disorders, APA, Washington.

DSM-IV (1994), Diagnostic and Statistical Manual of Mental Disorders, APA, Washington.

DSM-V (2013), Diagnostic and Statistical Manual of Mental disorders - $5^{\text {th }}$ edition, APA, Washington DC.

Gawda Barbara (2000), Samobójstwo a transgresje temporalne [w:] Problemy wspótczesnej tanatologii IV, red. J. Kolbuszewski, W'TN, Wrocław.

- (2003), Samobójstwo jako efekt braku akceptacji [w:] Problemy wspótczesnej tanatologii VII, red. J. Kolbuszewski, WTN, Wrocław.

- (2007a), Narracje o mitości osób z antyspoteczna osobowościa [w:] Bliżej emocji, red. A. Błachnio, A. Gózik, Wydawnictwo KUL, Lublin. 
- (2007b), Ekespresja pojéc afektywnych w narracjach osób z osobowościq antyspołeczna, Wydawnictwo UMCS, Lublin.

- (2010), Negacje w narracjach o miłości osób antyspołecznych [w:] Psychologia wobec matych i wielkich narracji, red. M. Straś-Romanowska, B. Bartosz, M. Żurko, Eneteia, Warszawa.

Hammen Constance (2004), Depresja, GWP, Gdańsk.

ICD-10 (1996), Międzynarodowa Statystycz̨na Klasyfikacja Chorób i Problemów Zdrowotnych, Vesalius, Kraków.

Jamison Key Redfield (2000), Niespokojny umyst. Pamiętnik nastrojów i szaleństwa, Zysk i s-ka, Poznań.

Kaup Barbara (2001), Negation and its impact on the accessibility of the text information, „Memory \& Cognition", nr 29.

Kurcz Ida (1987), Jezyye a reprezentacja świata w umyśle, Naukowe PWN, Warszawa.

Narracja jako sposób rozumienia świata (2002), red. J. Trzebiński, GWP, Gdańsk.

Ricoeur Paul (1989), Jezyke, tekst, interpretacja, PIW, Warszawa.

Rosner Katarzyna (2003), Narracja, to ¿̇samość i czas, Universitas, Kraków.

Stemplewska-Żakowicz Katarzyna (2002), Koncepcje narracyjnej tożsamości, Od historii życia do dialogowego ,ja” [w:] Narracja jako sposób rozumienia świata, red. J. Trzebiński, GWP, Gdańsk.

Straś-Romanowska Maria, Bartosz Bogna, Żurko Magdalena (2010a), Badania narracyjne w psychologii, Eneteia, Warszawa.

- (2010b), Psychologia matych i wielkich narracji, Eneteia, Warszawa.

Trzebiński Jerzy (2002), Narracyjne konstruowanie rzeczymistości [w:] Narracja jako sposób rozumienia śmiata, red. J. Trzebiński, GWP, Gdańsk. 